\title{
Flood analysis of the Limpopo River basin through past evolution reconstruction and a geomorphological approach
}

\author{
M. Spaliviero ${ }^{1}$, M. De Dapper ${ }^{2}$, and S. Maló ${ }^{3}$ \\ ${ }^{1}$ United Nations Human Settlements Programme, Nairobi, Kenya \\ ${ }^{2}$ Faculty of Sciences, Ghent University, Ghent, Belgium \\ ${ }^{3}$ Faculty of Arts and Social Sciences, Eduardo Mondlane University, Maputo, Mozambique \\ Correspondence to: M. Spaliviero (mathias.spaliviero@unhabitat.org)
}

Received: 31 December 2013 - Published in Nat. Hazards Earth Syst. Sci. Discuss.: 10 February 2014

Revised: 16 June 2014 - Accepted: 19 June 2014 - Published: 7 August 2014

\begin{abstract}
This research reconstructs the past evolution of the Limpopo River, a transboundary system located in southeastern Africa, and describes its geomorphological settings through a literature review and field work activities, with the aim of analysing flood hazard in the basin. Major changes have occurred since the late Jurassic-early Cretaceous period due to successive tectonic events. The paper demonstrates that the apparently abandoned drainage conformation of the palaeo-Limpopo in the upper and middle stretches of the river today constitutes preferential flood-prone areas in the case of major rainfall events. An important palaeo-delta is identified in the lower Limpopo, which imposes a particular drainage pattern onto the floodplain in Mozambique and influences the flood dynamics at present. The adopted method is helpful in determining flood hazard in a data-scarce area showing complex fluvial dynamics, and allows for the identification of unsuitable locations for human settlements.
\end{abstract}

\section{Introduction}

The Limpopo River belongs to a transboundary basin located in southeastern Africa, with its outlet in the Indian Ocean (see Fig. 1). Spaliviero et al. (2011) noted that human settlements tend to be concentrated closer to river streams due to the semi-arid or sub-humid conditions of the basin. These authors indicate that a demographic increase was registered in recent decades in the Botswana and South Africa sections of the basin, in the delta area and along the main river channel in Mozambique, as well as in the upper reaches of the basin in Zimbabwe, often in areas prone to flooding. The greater human density in these areas increases the level of vulnerability. It therefore becomes important to propose scientific methodologies that allow for the identification with a fair level of accuracy of unsuitable areas for developing human settlements, using the limited data available, and which can take into account the complex flood dynamics of the river.

Spaliviero (2003), while studying the Tagliamento River in northern Italy, concluded that flood hazards tend to be concentrated in the same locations where past fluvial changes occurred, allowing for the identification of areas under major risk. Similarly, this paper aims to perform a flood analysis in the Limpopo River basin based on a good understanding of its past and geomorphological characteristics.

As stated by Goudie (2005), a detailed and systematic understanding of the complex African drainage system still requires further investigation. This statement particularly applies to the southern African region. Specifically, we will try to answer the following question: do clear relationships exist between current flood hazard and past fluvial changes in the Limpopo River basin?

From a methodological perspective, the description of the river's past evolution is combined with a geomorphological approach. The paper first describes the actual geographical extent of the major flood events that occurred in the lower Limpopo River during the years 2000 and 2013. In the attempt to respond to the research question, it investigates the role played by tectonics (as underlined by Blum and Tornqvist, 2000) in determining major changes of the Limpopo River. In particular, it reconstructs the past river's development through an in-depth literature review regarding the geological evolution of southern Africa since the late 


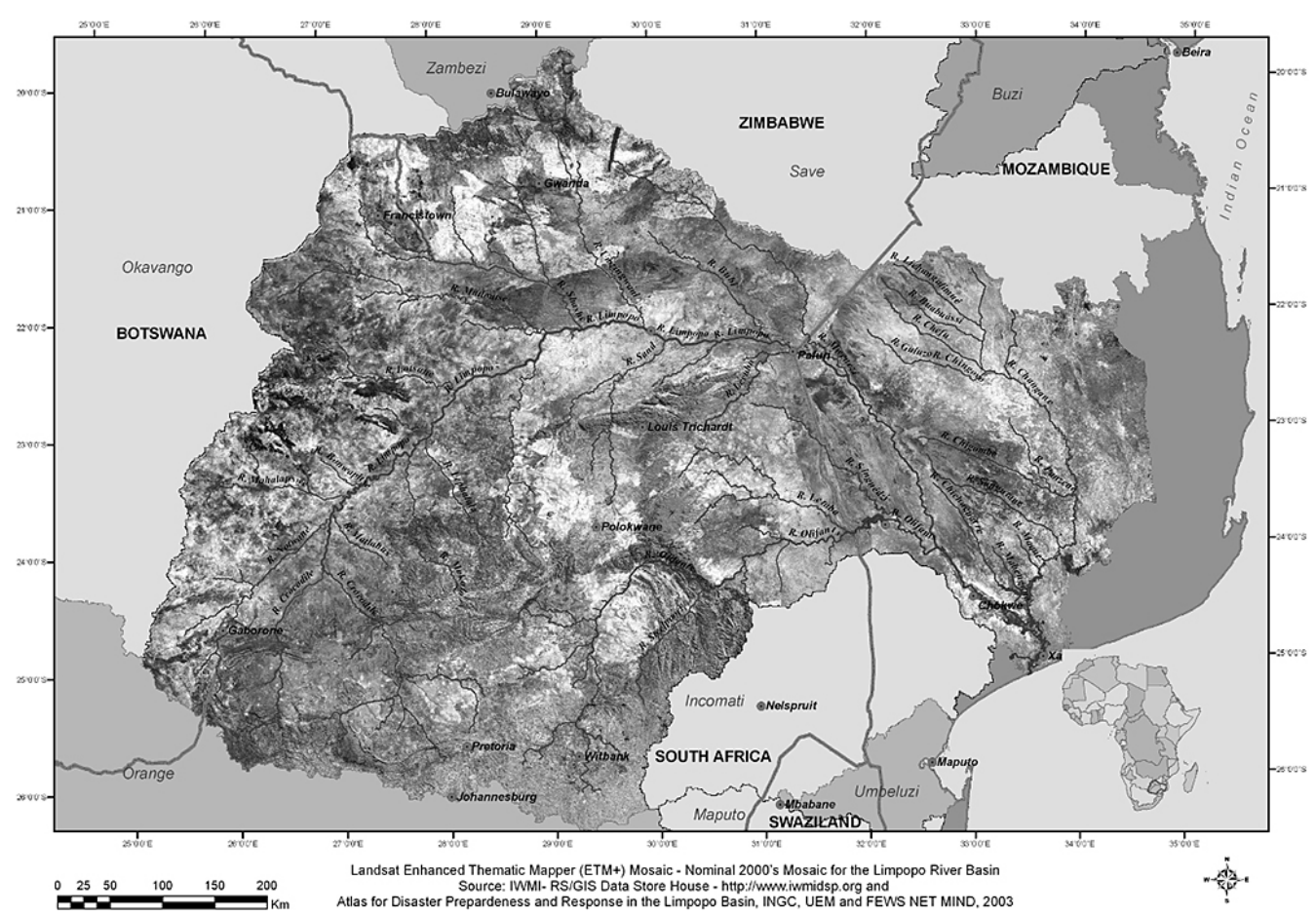

Figure 1. Satellite image mosaic of the Limpopo River basin by collating Landsat satellite images of $30 \mathrm{~m}$ resolution (source: Maló and Da Conceição, 2007).

Jurassic-early Cretaceous period. Finally, it collates data resulting from participatory land-use planning exercises undertaken in the upper-middle Limpopo and geomorphological observations made in the lower Limpopo during a field visit, to analyse how palaeo-drainage patterns are re-activated by the floods at present. In conclusion, the paper discusses the relevance of the approach proposed and its applicability for other complex river systems.

\section{Analysis of the 2000 and 2013 flood events in the lower Limpopo River}

A careful analysis of the geographical extent of the 2000 floods allows for the obtaining of a better understanding of the flood hazard in the lower Limpopo River basin. This dramatic event caused more than 700 deaths, displacing approximately 500000 people and affecting a total population of two million people (Kundzewicz et al., 2002).

In the radar satellite image in Fig. 2, the flooded areas appear in dark, while the maximum extent reached by the floods is indicated by the white arrows. To facilitate their identification, the maximum extent of the 2000 floods was digitised in blue in the figure. It is noted that in addition to the typical invasion of the larger floodplain along the lower Limpopo River itself, the topographically lower eastern part of what appears to be a palaeo-delta has been the area most affected by the 2000 floods, especially along the Changane

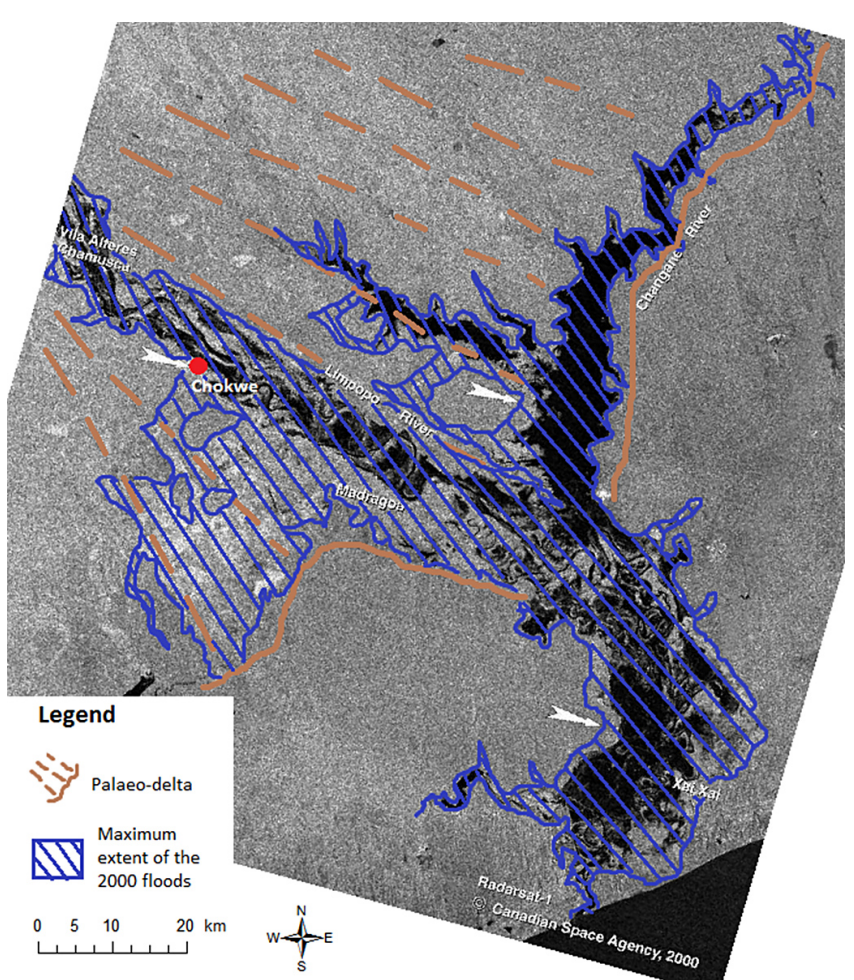

Figure 2. Radarsat-1 image recorded on 28 February 2000 (approximately $50 \mathrm{~m}$ spatial resolution) showing the maximum extent of the 2000 floods affecting the lower Limpopo. 


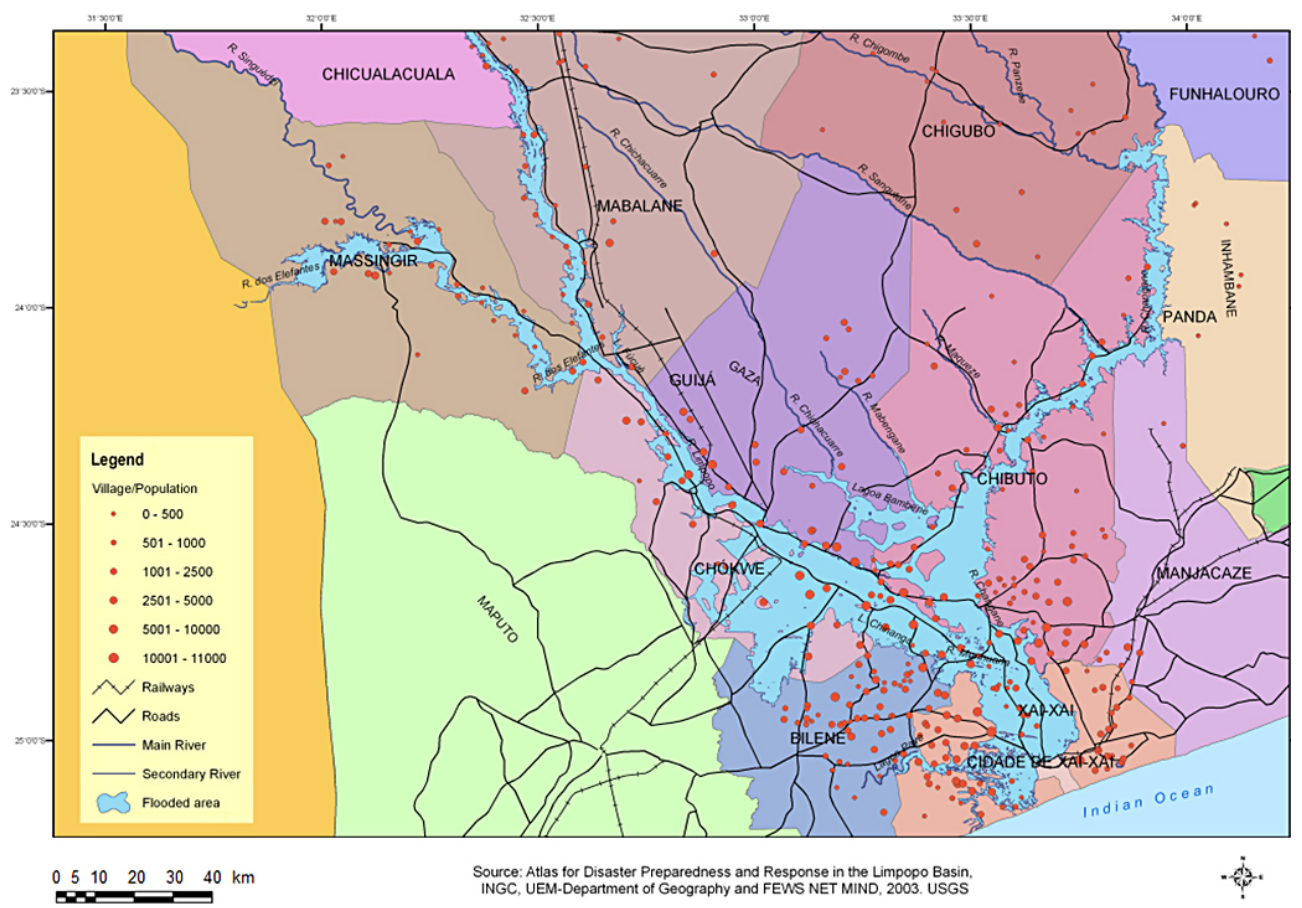

Figure 3. Maximum extent of the 2000 floods in Mozambique (source: INGC et al., 2003).

River, a major tributary. The map presented in Fig. 3 confirms this pattern, which extends southwards to the right bank of the Limpopo River. This corresponds to the area south of Chókwè that appears whitish in Fig. 2 (see the maximum extent of the floods).

To verify the accuracy of this interpretation, we now analyse the floods that occurred in January and February 2013 in the same area of the basin. This event caused approximately 50 deaths and displaced around 150000 people in the lower Limpopo River basin (OCHA ROSA, 2013). Interestingly, these floods followed the same dynamics of the 2000 event. Once again floodwaters have been concentrated along the lower area delimited by the same mega palaeo-delta (see Fig. 4).

Importantly, Fig. 3 shows clearly that the identified flooded areas also correspond to the highest concentration of human settlements. This can be explained by the human dependence on agricultural activity (the most fertile soils are there) and the basic need to live close to fresh water.

\section{The geological evolution of southern Africa since the Jurassic period and its influence on the Limpopo River's development}

For a better understanding of the current fluvial geomorphological settings of the Limpopo River basin, one needs to revert to the late Jurassic-early Cretaceous period corresponding broadly to the Gondwana disruption (separation of the supercontinent and formation of the existing continents due to plate tectonics). The sequence of events which successively changed the territorial morphology of southern Africa from the Jurassic to the present consisted in cycles of erosion (Maufe, 1935; King, 1963; Lister, 1987; Partridge and Maud, 1987). According to the pioneering interpretation of Du Toit (1933), which has then been substantiated by the findings of Moore (1999), Moore and Blenkinsop (2002), Cotterill (2003), and Moore et al. (2007, 2008, 2009a, b), the referred erosion cycles were primarily triggered by crustal movements determining periodically new drainage patterns. These movements were derived from complex plate tectonic dynamics associated with rifting processes and deeporiginating mantle plumes, resulting in crustal flexuring or warping.

Volcanic eruptions of the Karoo, which Moore and Blenkinsop (2002) estimated to have occurred from the Permo-Carboniferous to the lower Cretaceous period in association with the Gondwana fragmentation, have provoked a major reorganisation of the drainage system in southern Africa. By that time, the Karoo plume (see the location in Fig. 5), which is linked to the opening of the Indian Ocean, initially imposed a westwards flowing drainage pattern due to its doming effect. This pattern was reverted 40-50 million years later (approximately during the early Cretaceous) to a predominantly eastwards flowing system, due to the opening of the Atlantic Ocean related to the Paraná plume (see Fig. 5). While referring to White (1997), Moore and Blenkinsop (2002) explain that such a change in the flowing direction was also magnified by the subsidence of the Mozambique 

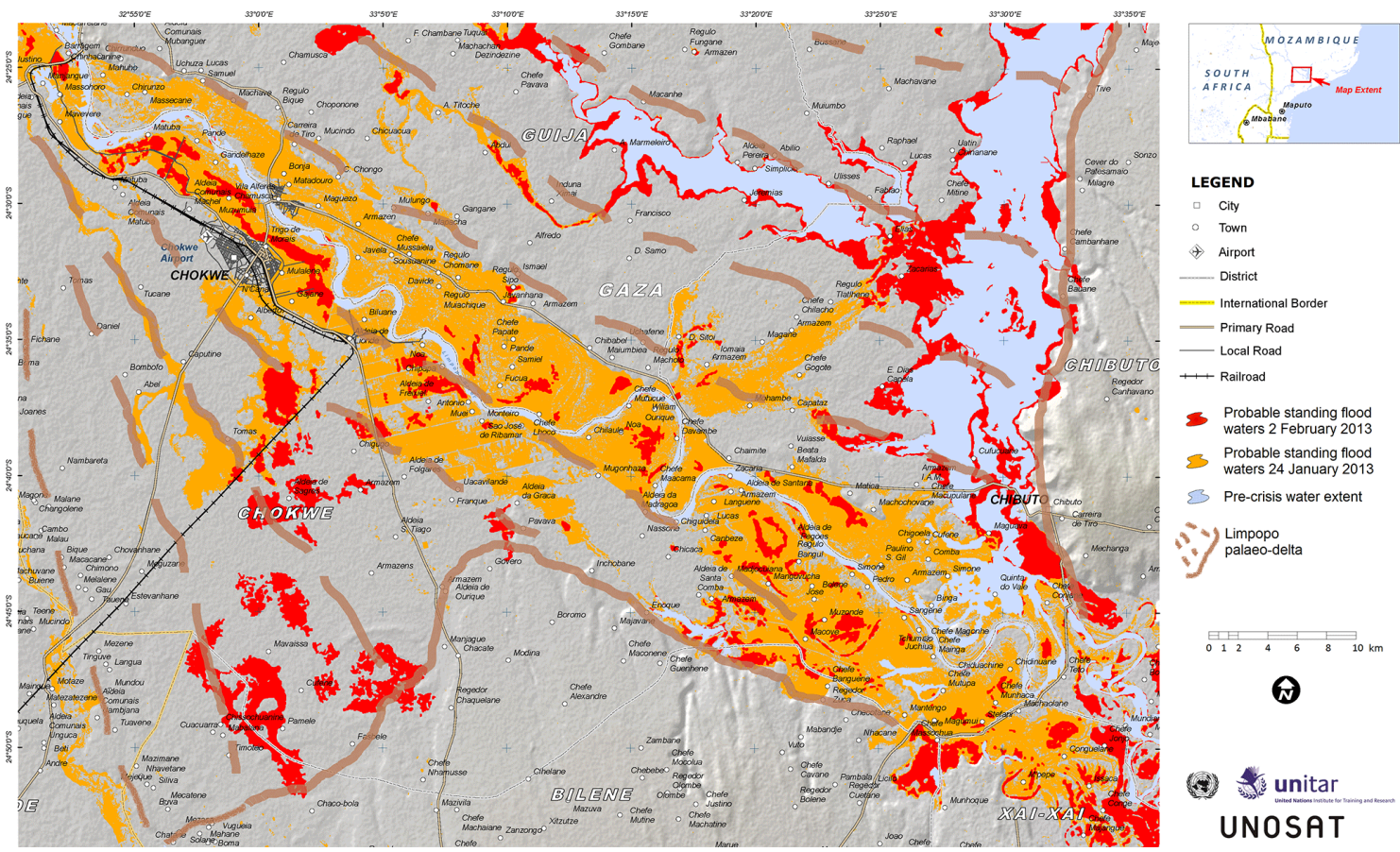

LEGEND

$\square$ City

- Town

† Airport

_-._- District

_- International Border

- Primary Road

- Local Road

+ Railroad

- Probable standing flood

3 Probable standing flood

3 Pre-crisis water extent

$\rightarrow$ Limpopo

. palaeo-delta

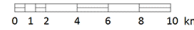

(2)

(9) unitar

UNOSAT

Figure 4. Analysis of the 2013 flood extent in the lower Limpopo River through satellite image interpretation (adapted from http://www. unitar.org/unosat/maps/MOZ, last access 2 February 2013).

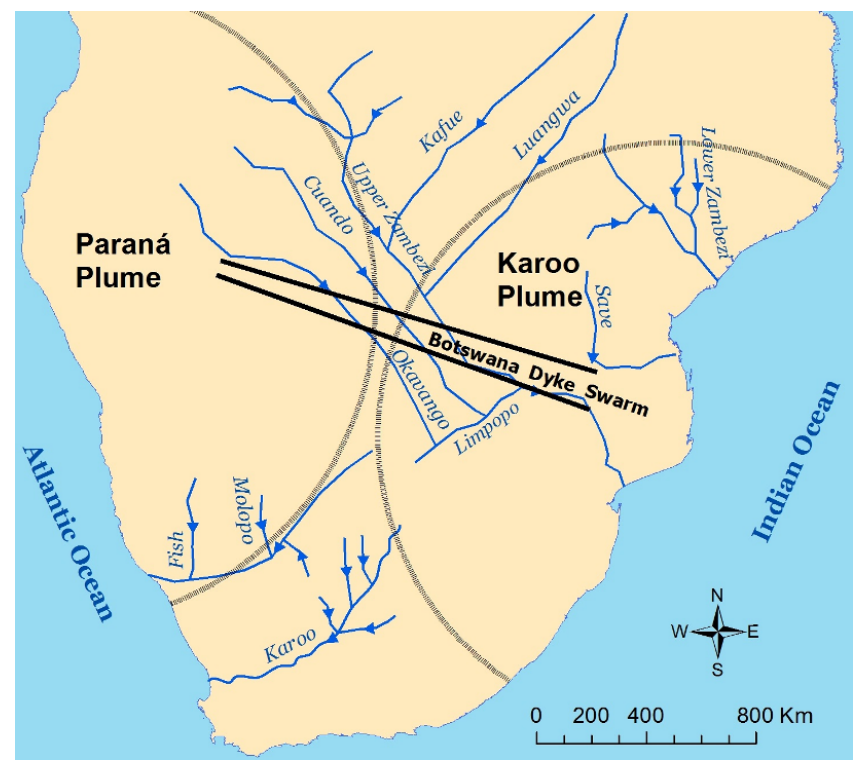

Figure 5. Main drainage system of southern Africa during the early Cretaceous period (adapted from Moore, 1999).

plain during the same period as a result of sediment loading. The east still represents the dominant flowing direction of the fluvial system in southern Africa today, with Mozambique, located downstream, receiving nine international rivers in its territory.
Figure 5 is derived from the drainage reconstructions of Moore (1999), who based some of his deductions on early intuitions of Du Toit (1933) later confirmed by De Wit (1999), Moore and Larkin (2001) and Goudie (2005). It shows clearly that the palaeo-Limpopo River during the early Cretaceous period was by far the largest river of southern Africa, as it also included the southeastwards flowing Cuando, Okavango and upper Zambezi rivers as its main tributaries. The latter, which was most probably linked to the Limpopo through the Shashe River (Moore and Larkin, 2001), received waters from the Kafue and Luangwa rivers originally flowing in a southwesterly direction (Moore and Blenkinsop, 2002).

Moore and Blenkinsop (2002) and Moore et al. (2007) indicate that the palaeo-Limpopo River entered the coastal plain of Mozambique by exploiting the corridor traced by the Botswana dyke swarm oriented along a east-northwest direction (see Fig. 5). This important geological feature, related to the disruption of Gondwana and its associated volcanism, further confirms the rift control over important and long-lived drainage lines (Potter, 1978; Moore et al., 2007, 2009a). In addition, Moore et al. (2007) highlight the parallel southeast and southwest patterns of this major river system, which again confirms an important geological structural influence on the drainage pattern.

In his influential article, Moore (1999), based on preliminary suggestions from Du Toit (1933), identified three main axes of crustal flexure (see Fig. 6) that arose due to plate 
tectonics in southern Africa. These axes of uplifting, which define the divides of important river watersheds today, have much influenced the drainage evolution in the region by determining successive river cuts and river captures (Moore and Larkin, 2001). According to Moore (1999) and Moore et al. (2009b), they appeared in the following chronological order:

- Late Jurassic-early Cretaceous: uplifting of the Escarpment Axis running parallel to the coastline and linked to the rifting process that initiated the breakdown of Gondwana (Partridge and Maud, 1987). The formation of this major geological feature started the erosion cycles which produced the "African Surface" (as it is often referred to in the scientific literature) for the region, on top of which were progressively deposited the sediments leading to the Kalahari formation.

- Late Cretaceous: uplifting along the EtoshaGriqualand-Transvaal (EGT) Axis, further closing the southern margin of the Kalahari formation (which today is a desert) and triggering the sedimentation process in the Kalahari. The latter started to sink slowly due to subsidence and became a large basin. This axis defines the southern limits of the Limpopo River basin by separating it from the Orange River system.

- Late Palaeogene: uplifting along the OvamboKalahari-Zimbabwe (OKZ) Axis that has rejuvenated the main drainages and initiated the erosion of the coastal side of the flexure. This geological feature forms the local boundary of the Kalahari formation. Importantly, according to Moore (1999), the uplifting of the OKZ Axis cuts across the line of the Okavango and was therefore responsible for breaking the link with the Limpopo River by the end of the Cretaceous period (see the squared area in Fig. 6), as originally predicted by Du Toit (1933). As a consequence, the Okavango, upper Zambezi (which included the Kafue and Lwangua rivers) and Cuando rivers, all attached to the palaeo-Limpopo River, became a huge endoreic drainage system. The latter supplied sediment to the Okavango and Makgadigadi depressions, originally identified by Du Toit (1933) as part of the Kalahari basin. Both the upper Zambezi and Cuando rivers would then be captured by the lower Zambezi during the Upper Pleistocene (Moore and Larkin, 2001; Moore et al., 2007).

The inferred ages of the axes of flexure described above correspond to three major peaks in volcanic activity in the region (Moore, 1999). In addition, parts of these axes increased their height during the Plio-Pleistocene period along a northeastsouthwest direction (King, 1963; Partridge, 1998). This means that the more recent crustal flexures are probably associated with the continuation of the Great Rift Valley, which

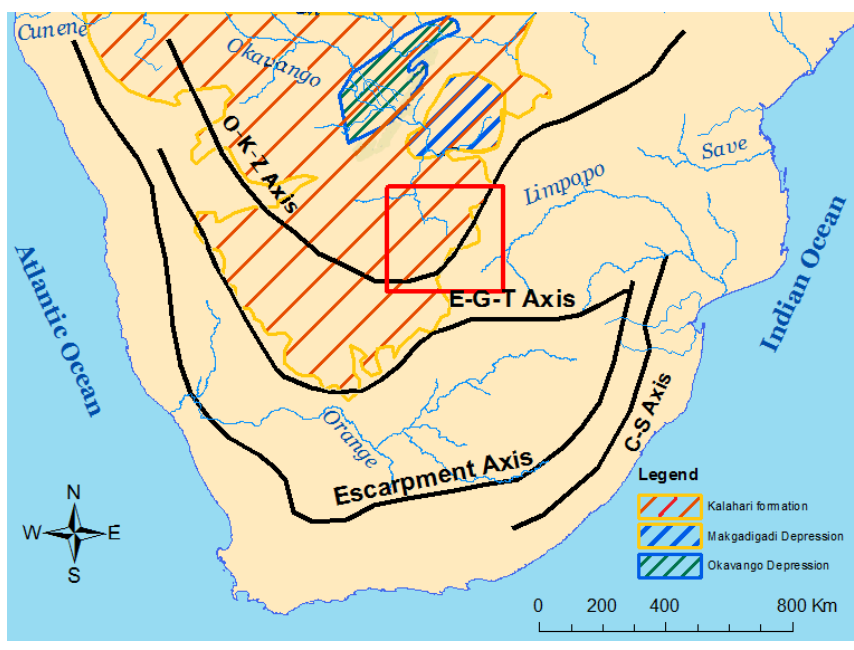

Figure 6. Axes of crustal flexure of southern Africa defining the major water divides (adapted from Moore, 1999).

may determine an additional break-up of the African continent in the future. It is therefore suggested that these phenomena (volcanism and recent crustal flexuring) are linked to a common underlying tectonic/geological process (Moore, 1999).

Importantly, the three identified axes of flexure, namely the Escarpment Axis, the EGT Axis and the OKZ Axis, show a sequential uplifting according to a concentric pattern developing farther inland (Moore, 1999). This triggered successive river rejuvenation on the coastal side of each axis of flexure, and hence activated the previously mentioned cycles of erosion (Moore et al., 2009b).

\section{Linkages between the geomorphological evolution of the upper-middle Limpopo River and flood hazard}

The following scientific observations provide evidence of the disruption of the palaeo-Limpopo River due to the uplifting of the above-mentioned OKZ Axis of crustal flexure during the late Cretaceous-early Tertiary period:

- While the isopachs of the sub-Kalahari valley show a northwesterly flowing direction of the now abandoned Okavango River, the distribution of the ilmenites derived from the Orapa kimberlite field located to the north implies that this river originally flowed towards the southeasterly direction (Moore, 1999).

- The uplifting of the OKZ Axis determined several abandoned tributaries of the Limpopo, especially in Botswana up to the border with Zimbabwe. There are river channels showing a width and gravel size which cannot be explained by an ephemeral flow, thus constituting evidence that they were part of a major drainage system (Moore and Larkin, 2001). 


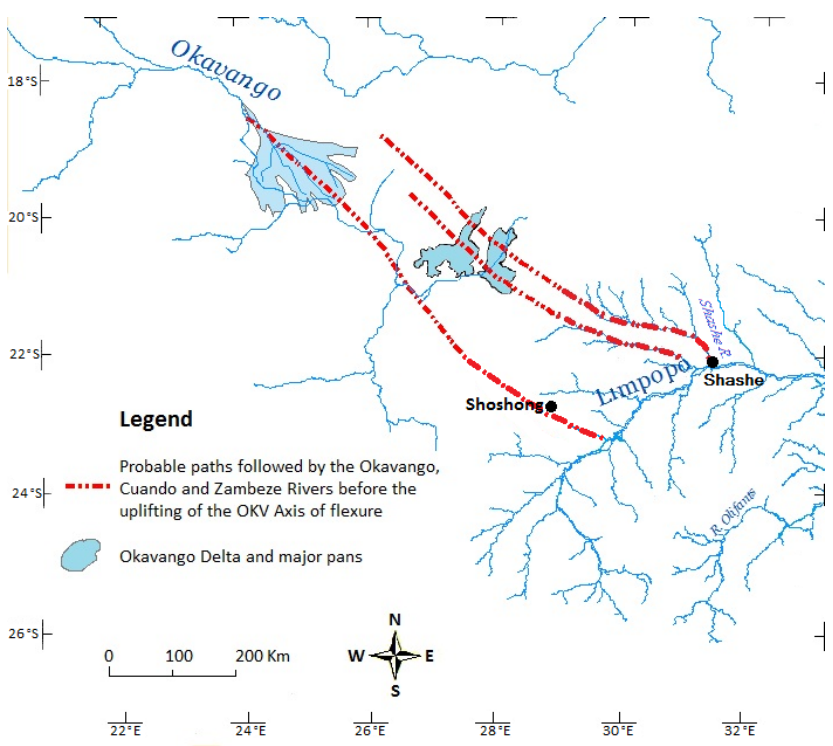

Figure 7. Probable paths followed by the Okavango, Cuando and Zambezi rivers when they were still major tributaries of the palaeoLimpopo River (adapted from Moore and Larkin, 2001).

- Moore et al. (2007) provide scientific references showing the occurrence of common fish and plant species between the Okavango and Limpopo rivers, which confirms that they belonged to the same drainage system in the past.

Figure 7 shows the probable paths followed by the Okavango, Cuando and upper Zambezi rivers when they were still major tributaries of the palaeo-Limpopo River during the Cretaceous period.

Participatory land-use plans were prepared at various locations of the Limpopo River basin during a sub-regional project implemented between 2004 and 2007 by the United Nations Human Settlements Programme (UN-Habitat) in collaboration with the United Nations Environment Programme (UNEP). More details about this initiative can be found in Spaliviero et al. (2011). Each riparian country was requested to select particularly flood-prone settlements to implement this activity. The government of Botswana indicated Shoshong village (see location in Fig. 7), which is crossed by a homonymous river system that reaches the Bonwapitse River, a tributary of the Limpopo River.

According to the information collected by Mpho (2007), Shoshong is regularly affected by flash floods during the rainy season. Major events have occurred every five years on average since the 1990s, causing severe losses of crops, livestock, physical property and sometimes even human life. In fact, this settlement of approximately 10000 inhabitants is located in the middle of a former wide and important fluvial braiding system belonging to the Okavango River before the raising of the OKZ Axis of crustal flexure. The map in Fig. 8 shows clearly the high level of risk of Shoshong, with most

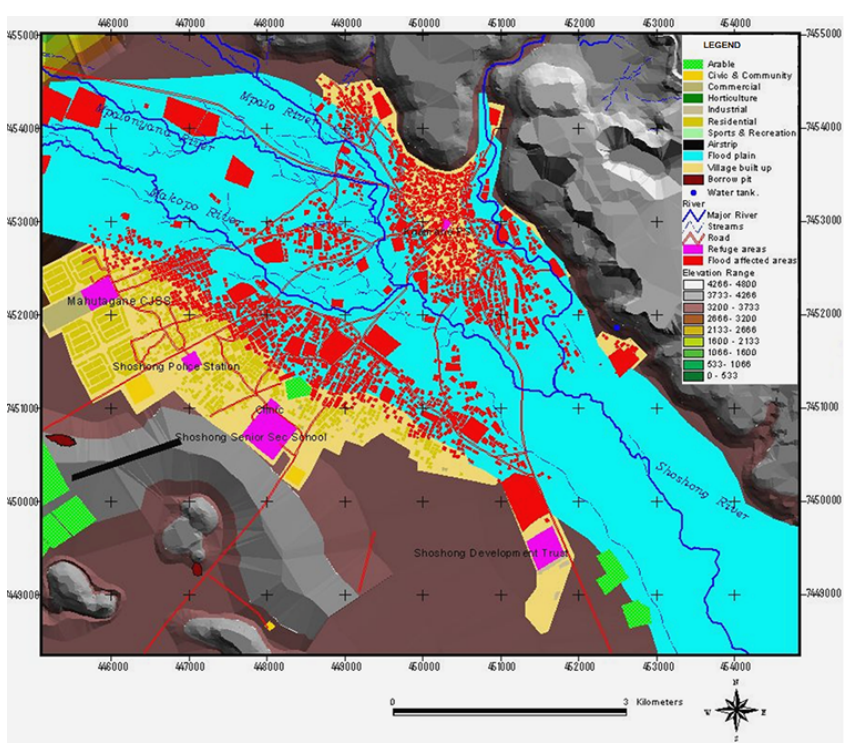

Figure 8. Flood risk map of the Shoshong settlement, Botswana (source: Maló and Da Conceição, 2007).

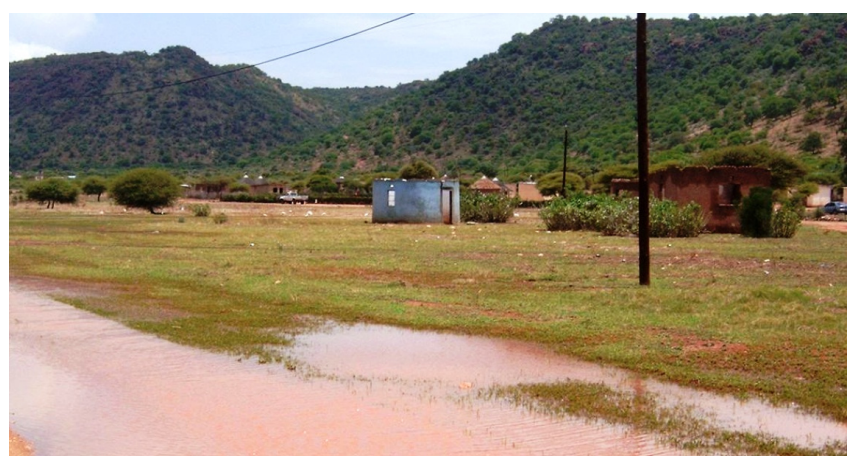

Figure 9. Abandoned houses in the Shoshong floodplain (photographer: Mpho, 2007).

of its built-up area lying in the floodplain (see also Fig. 9). The Shoshong River, despite being dried over long periods of time, can suddenly be reactivated after persistent rainfall. This occurs essentially because its current geomorphological settings are the result of a much more important fluvial regime in the past, when the Okavango was a major tributary of the palaeo-Limpopo River. We can therefore conclude that most of the Shoshong settlement is located in an area prone to endemic floods.

Moore and Larkin (2001) infer that the important width of the floodplain of the Shashe River at its confluence with the Limpopo (more than $2 \mathrm{~km}$ - see Fig. 10) can be explained by the former course of the Cuando River. It maintained a southeasterly course and was part of the palaeo-Limpopo River (see Fig. 5) before being captured by the Zambezi drainage system as a consequence of the uplifting of the OKZ Axis of flexure. 


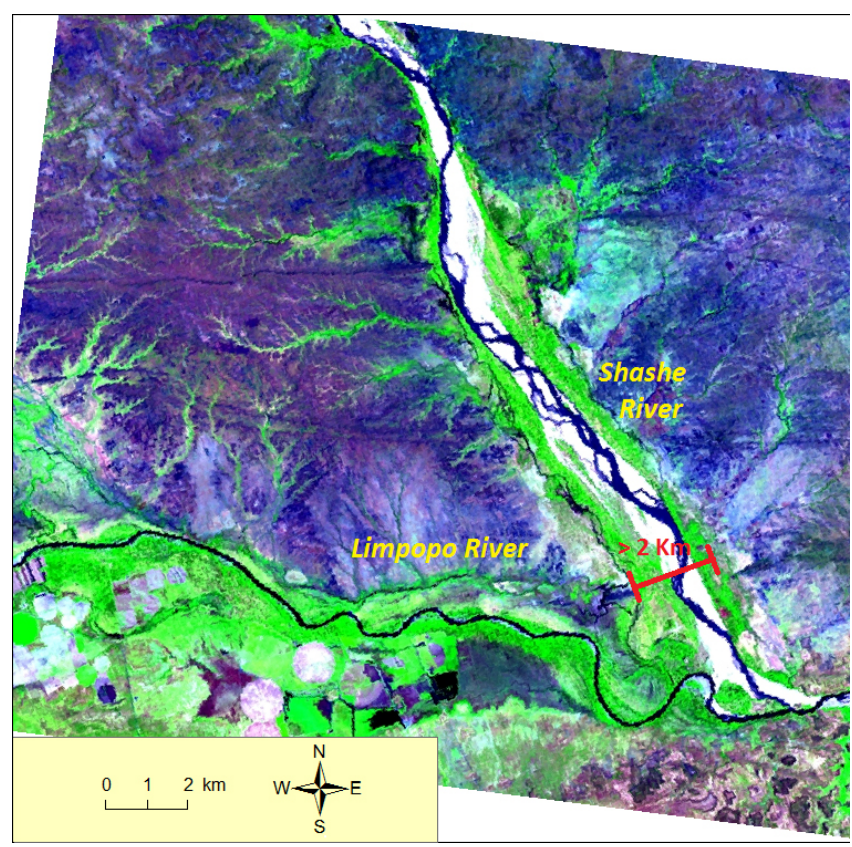

Figure 10. False colour-composite Landsat 7 satellite image of 2000 (30 m resolution) showing the confluence between the Shashe and Limpopo rivers.

Similar to what has been observed in Shoshong in Botswana, the confluence of the Shashe River is considered to be one of the locations most vulnerable to flooding in Zimbabwe along the Limpopo River today. This is confirmed by the participatory land-use plan regarding the Shashe study area prepared by Murwira et al. (2006) within the framework of the mentioned UN-Habitat/UNEP Limpopo project. The local communities reported the loss of property and crops, and the destruction of infrastructure due to recurrent flooding. Figure 11 shows clearly that approximately $65 \%$ of Shashe's population lives in areas of high flood hazard.

\section{Linkages between the geomorphological evolution of the lower Limpopo River and the flood hazard}

According to Du Toit (1933), a great part of the plain lying in southern Mozambique (hereafter referred to as the "southern Mozambique plain") is built of Cretaceous, Tertiary and Pleistocene sediments which have been raised above sea level. These sediments result from river deposits that occurred during different geological periods, particularly as a consequence of the successive erosion cycles induced by the crustal uplifting events. A chronological description of the past events leading to the formation of the southern Mozambique plain, where the lower Limpopo River has flowed since the Jurassic period, follows:

- As mentioned earlier, the Limpopo River entered the southern Mozambique plain by exploiting the crustal

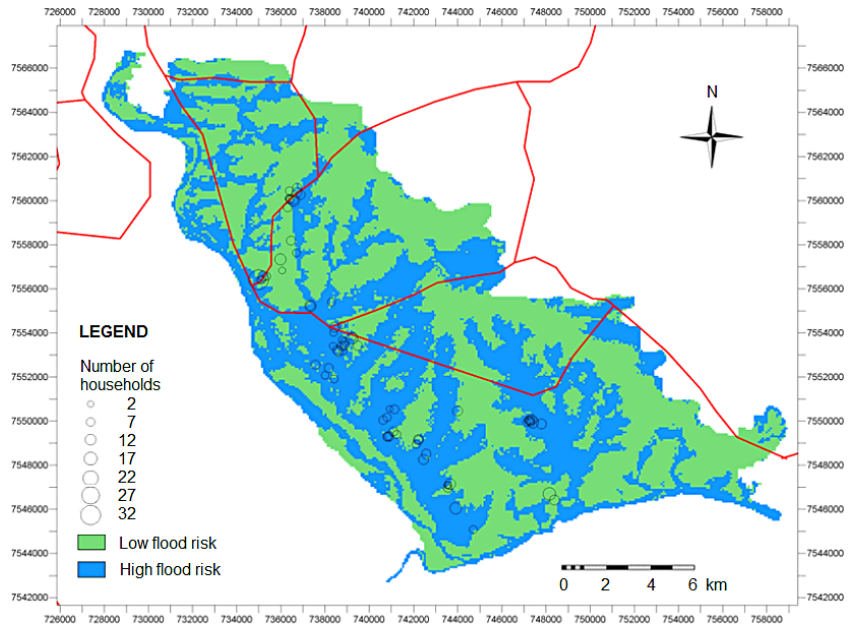

Figure 11. Flood risk map of the Shashe area (source: Murwira et al., 2006).

opening made by the Botswana dyke swarm associated with the Gondwana break-up (Moore and Blenkinsop, 2002; Moore et al., 2007), as shown in Fig. 5. This fluvial system has therefore built up the southern Mozambique plain through successive erosion periods by flowing mainly through that same corridor (where the Pafuri settlement can be found today) during at least the past 130-150 million years. This has had important implications for the geomorphological settings of the lower Limpopo River, as it has facilitated the formation of a mega-fluvial delta.

- Moore and Larkin (2001) refer to the presence of a prominent seaward bulge in the coastal plain of Mozambique lying between Beira and Maputo. They indicate that a sequence of sediments of $1.3-2 \mathrm{~km}$ in thickness dating from the disruption of Gondwanaland (Jurassic to lower Cretaceous) can be found in the middle of the plain, parallel to the coastline. Much earlier, Dixey (1955) explained that the great thickness of Cretaceous terrestrial sediments observed in this area shows that the coastline at that time was located much farther east compared to its current location. This is consistent with the fact that the palaeo-Limpopo River was by far the most important fluvial system of southern Africa at that time, bringing huge loads of sediments to the eastern coast and progressively building up the southern Mozambique plain. Accordingly, Burke (1996) indicates that this ancient river formed an important delta during the Jurassic-Cretaceous period (see Fig. 12). We note with interest that this palaeo-delta is proportional to the size the river basin had during that period. There can be no other explanation for the formation of such a huge deltaic system. When referring to the thermal history data of organic material collected in deep wells 


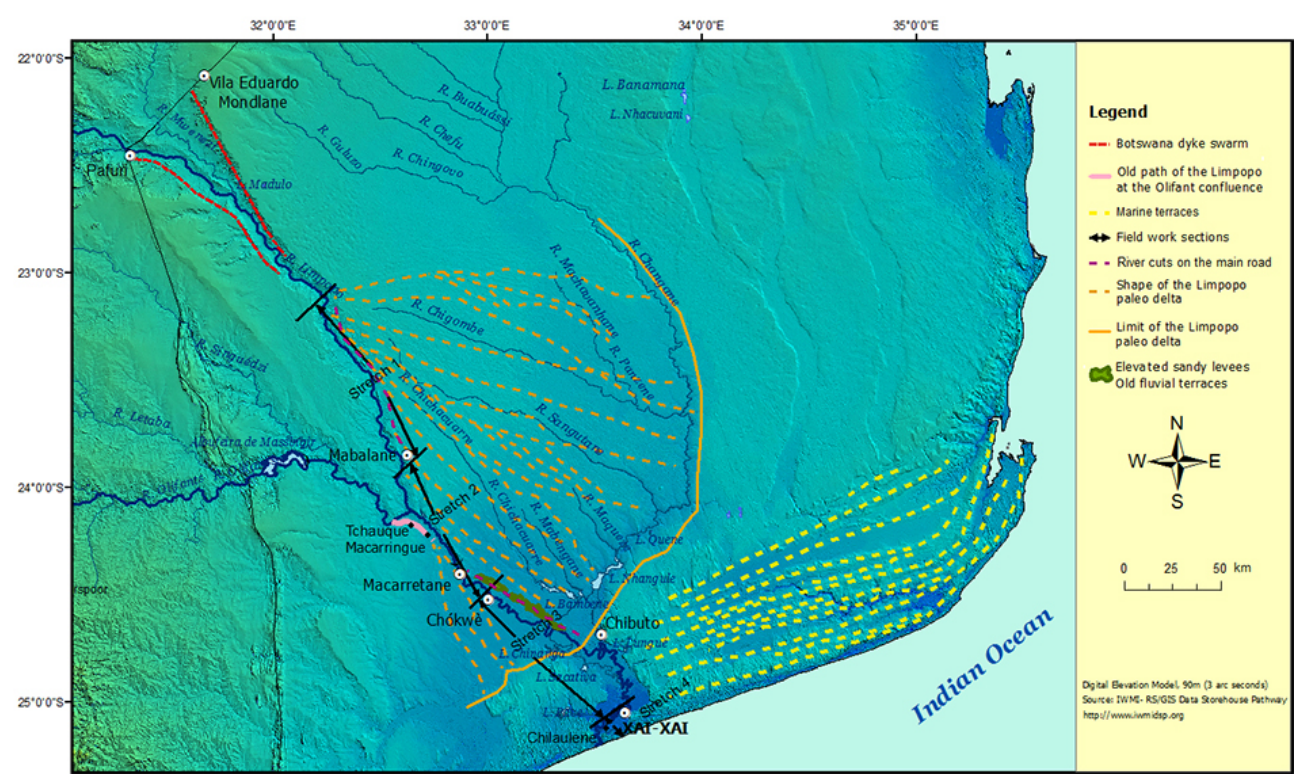

Figure 12. Main geomorphological features of the lower Limpopo River.

in the southern Mozambique plain, Burke and Gunnel (2008) confirm that, stratigraphically, the upper part of the delta complex started to form during the early Jurassic. These authors, by citing Wilkinson (2004), also mention the existence of a megafan in correspondence to the lower Limpopo River, together with another fourteen megafans scattered all over the African continent, which have not yet been investigated sufficiently.

- As mentioned earlier, the coastal plain of Mozambique started to sink progressively by the early Cretaceous due to the enormous amount of sediment deposited (White, 1997). This is again consistent with the great size of the palaeo-Limpopo at that time, and is confirmed by the data presented by Burke and Gunnel (2008).

- Moore and Larkin (2001) refer to a net reduction in sediment supply to the southern Mozambique plain by the lower Tertiary. This probably corresponds to the beginning of the uplifting process of the OKZ Axis of crustal flexure during the late Palaeogene suggested by Moore (1999), cutting off the Okavango, Cuando and upper Zambezi rivers from the Limpopo River basin. This is also confirmed by Salman and Abdula (1995), who state that there was no active Limpopo delta during the early Cenozoic (between approximately 65 and 30 million years ago). According to Moore et al. (2009a), the uplifting of the OKZ Axis then rejuvenated the drainage system and provoked a new cycle of erosion that caused an increase in sediment supply during the Oligocene period. This triggered the displacement of the Limpopo River mouth southwards during the same period (Moore and Larkin, 2001). We suggest that any drainage modification of the lower Limpopo River, as a consequence of crustal flexuring events which occurred after the existence of the palaeoLimpopo River, could most probably not have escaped from the morphological conformation imposed by the huge delta or megafan of such an ancient river.

- The last major geological event which influenced the overall morphology of the southern Mozambique plain was probably the general uplifting which occurred during the Plio-Pleistocene period (Maufe, 1935; Moore, 1999; Moore and Larkin, 2001). Partridge (1998) mentioned the uplifting of the Ciskei-Swaziland (C-S) Axis of crustal flexure during the same period, which is located between the Great Escarpment Axis and the current eastern coastline of southern Africa (see Fig. 5). This must have been an abnormally swift process in raising the Tertiary sediments (Du Toit, 1933; Moore and Larkin, 2001), which were previously submerged and reworked by the sea to form the present coastal plain. Such an uplift is also confirmed by Salman and Abdula (1995). Lister (1987) identified young Pliocene age sedimentary surfaces in the Mozambique plain, most probably formed by an additional drainage rejuvenation triggered by the raising of the same $\mathrm{C}-\mathrm{S}$ Axis. Interestingly, Du Toit (1933) explains the high speed of this general uplift by describing the topographical profile of the main southern African rivers crossing this axis. This profile is slightly convex upwards, which proves that the erosional process has been slower than the uplifting. Furthermore, the series of parallel marine terraces indicated in Fig. 12 are probably features resulting from this rapid uplifting process. 
In October 2009, the authors of this paper conducted fieldwork in the lower Limpopo to examine the geomorphological settings of the area. Their findings, presented below according to four river stretches starting from the apex of the megafan to the Indian Ocean (see Fig. 12), confirm most of the aspects mentioned above.

\subsection{Stretch 1: from the mega-delta apex to south of Mabalane}

At the megafan apex we observed not fully consolidated conglomerates, probably dating from the Tertiary (see Fig. 13). The weathered, incised and terraced river gravels are possibly associated with the crustal uplifting that occurred during the Pliocene-Pleistocene period. This is much older than the terrace observed in the Macarretane area (see Fig. 12). Several river cuts are observed along the Macarretane-Vila Eduardo Mondlane road, especially to the north and south of the Mabalane area. These cuts were probably determined by the floods, showing a fluvial tendency to reactivate the palaeodeltaic system.

\subsection{Stretch 2: from the Olifants-Limpopo river confluence to Chókwè}

In the lower Limpopo area, the confluence with the Olifants River represents a critically vulnerable location. In fact, fieldwork and interviews with the local population confirmed that the settlements in that area, in particular Tchauque and Macaringue (see the map in Fig. 12), were completely surrounded by water during the 2000 floods.

A photo taken close to the confluence (see Fig. 14), where a data gauging station is located, shows the elevation reached by the high water mark. A closer interpretation of the relief of the confluence indicates that most probably the riverbed followed a different path in the past, slightly to the west of its current position, as interpreted in Fig. 12. This old path is reactivated in the case of major floods, as occurred in February 2000. The number, size and depth of round boulders found deposited in the quarries close to the confluence (see Fig. 15) and at Macarretane confirm that the Limpopo River at this stretch was a much larger fluvial system in the past.

\subsection{Stretch 3: from Chókwè to Xai-Xai}

On this stretch, we find a complex system of elevated and old sandy levees (see Fig. 16). On top of these levees, which run parallel to the fluvial system, are located the first organised human settlements of the lower Limpopo in correspondence to the Bantu migration to southern Africa, which occurred approximately 3000 years ago. Interestingly, the levees also host the burial site of the heroic traditional leader Ngungunhane (1895). These geomorphological features represent elevated and secure locations away from the flood hazard areas; a higher concentration of human settlements can

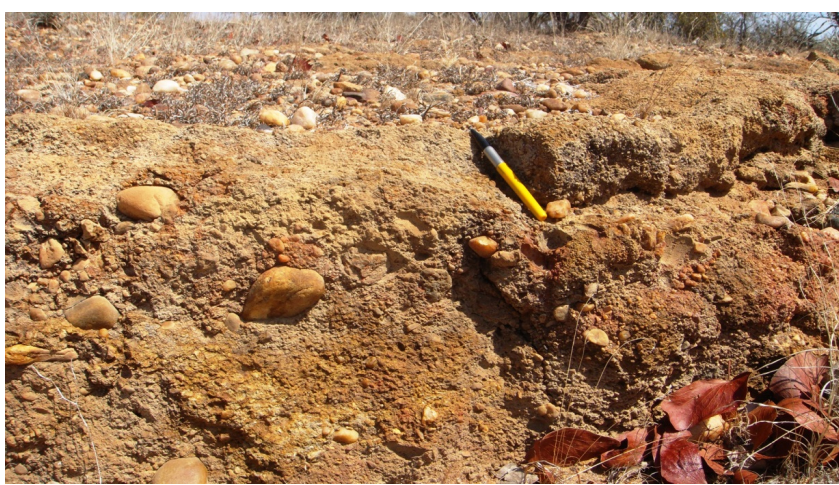

Figure 13. Weathered, incised and terraced river gravels at the apex of the megafan (photographer: De Dapper, 2009).

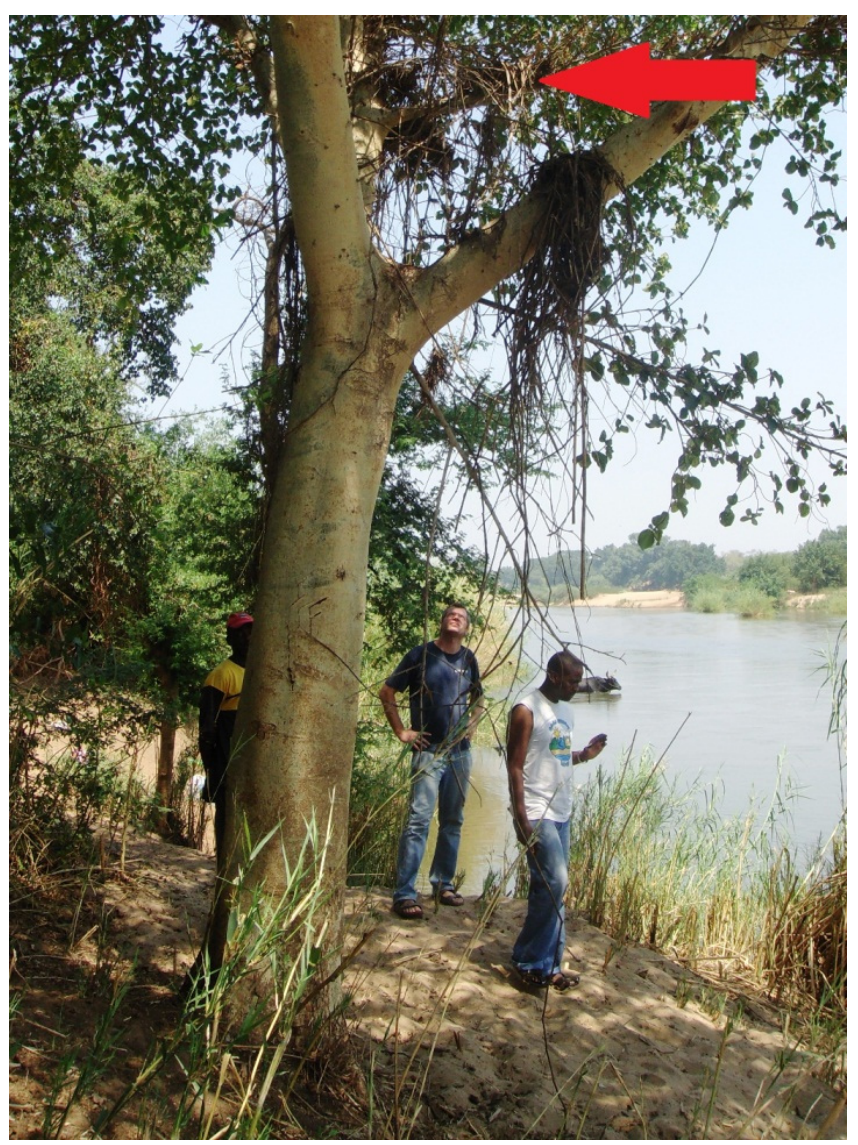

Figure 14. High water mark at the Olifants-Limpopo confluence (photographer: De Dapper, 2009).

thus be found there, including a railway system built by the Portuguese during the colonial era.

The settlement process was accompanied by a change in land use, shifting from forest to agriculture. The deforestation caused ravine erosion - contributing to sedimentation - which is still very pronounced today, especially in the Chibuto area, a compacted old dune system. 


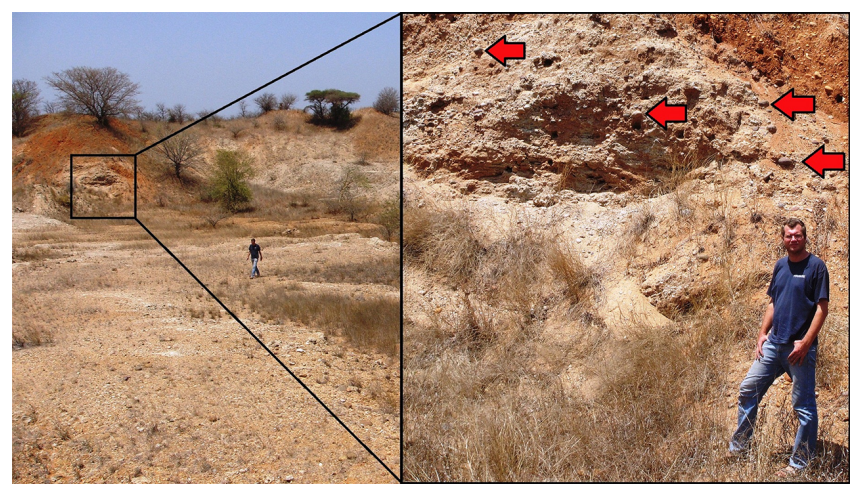

Figure 15. Round boulder deposit at a quarry close to the Olifants River's confluence (photographer: De Dapper, 2009).

The area of confluence between the Changane and Limpopo rivers (see Fig. 12) is particularly complex from a topographical point of view, and highly susceptible to flooding (see Fig. 2). It is a large depressed area, probably due to the subsidence process caused by the load of sediment, since it corresponds to a critical depositional area of the palaeodelta. A multitude of large abandoned meanders can be found in this stretch, again confirming the presence of a much bigger fluvial system as part of the megafan.

\subsection{Stretch 4: from Xai-Xai to the Limpopo River outlet}

The territorial morphology of the lowest part of the Limpopo River shows a strong marine influence. A complex and consolidated sand dune system distributed along the coastline seems to have diverted the river from its original southwards course towards the southwest direction to reach the Indian Ocean, as shown on the map in Fig. 17. In fact, during the dry period, the sea tide influence reaches beyond Xai-Xai, the capital of Gaza Province located some $15 \mathrm{~km}$ away from the coast. Some important irrigation schemes can therefore be observed in this area, which are provided with sluice systems to protect the agricultural crops from salty water invasion. Several of these irrigation schemes were completely destroyed during the 2000 floods.

The map shown in Fig. 17, which is derived from fieldwork and satellite image interpretation, describes both the dynamics and the extent reached by the waters during this flood event. The dykes were broken by the spinning force of the floodwaters, which formed whirlpools. As a result, the community living on top of the sand dune of Chilaulene, located in the middle of the floodplain, was flooded from river waters coming from different directions and was completely isolated for weeks. Mapping the flood dynamics allows better planning of flood mitigation measures.

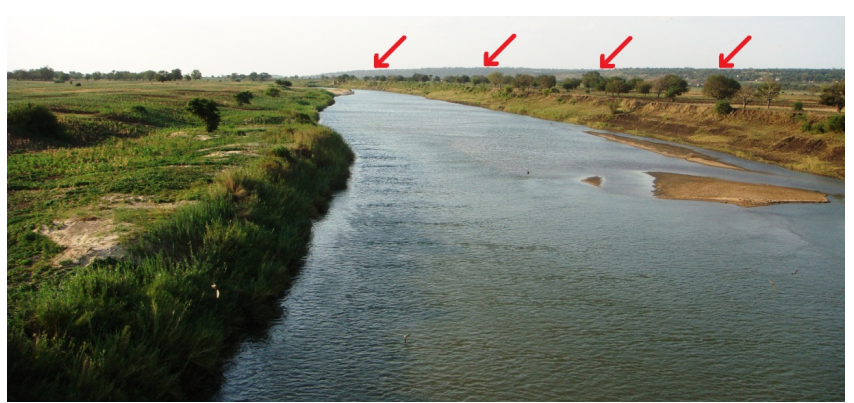

Figure 16. The Limpopo River flowing next to Chibuto; elevated sandy levees can be observed at the horizon on the right side, as indicated by the red arrows (photographer: De Dapper, 2009).

\section{Discussion and conclusion}

The complexity of fluvial dynamics and the morphological settings of any river basin, as well as the difficulty in reproducing the effects of anthropogenic intervention and extreme flood events, are factors that limit the adoption of spatially distributed dynamic modelling for improving flood risk management at basin level. Baker and Twidale (1991) affirm that "theoretical models may fail to account for the field evidence and the larger spatio-temporal domain". This view is also supported by Baker (1994) and Pilkey and Pilkey-Jarvis (2007).

The development of flood dynamic models requires the gathering of a high number of data (Parker et al., 2008) during a consistent number of years, and the use of many variables (Hickin, 1983). Access to accurate data is often a problem (Fohrer, 2003), particularly in developing countries, as it involves high costs and adequate institutional capacity. Large-basin channel response to a particular impact in a given time period is contingent upon all previous events (Wallick et al., 2007; Pahuja and Goswami, 2006). Threshold phenomena, which cause a rapid and often unpredictable change of state in systems, as it occurs for river channels (Newson, 2002), provide additional levels of complexity, and simulation results become difficult to control (Kauffman, 2002; Parker et al., 2008).

Alternative flood risk assessment and management approaches therefore need to be explored at river basin level. Steinberg (2004) acknowledges that, unfortunately, Man's perception of the river flow is limited and not consistent with a river's dynamic flooding and meandering history. In fact, to manage rivers and their related flood risk adequately, it is important to understand their evolution and nature, which can be done by investigating their past. Geomorphological flood analysis results from a long tradition of studying real processes operating in historical times, which are recorded in the sediments, landforms and erosional scars of past floods (Baker, 1994). As indicated by Gilvear (1999), fluvial geomorphology has the ability to recognise the significance of 


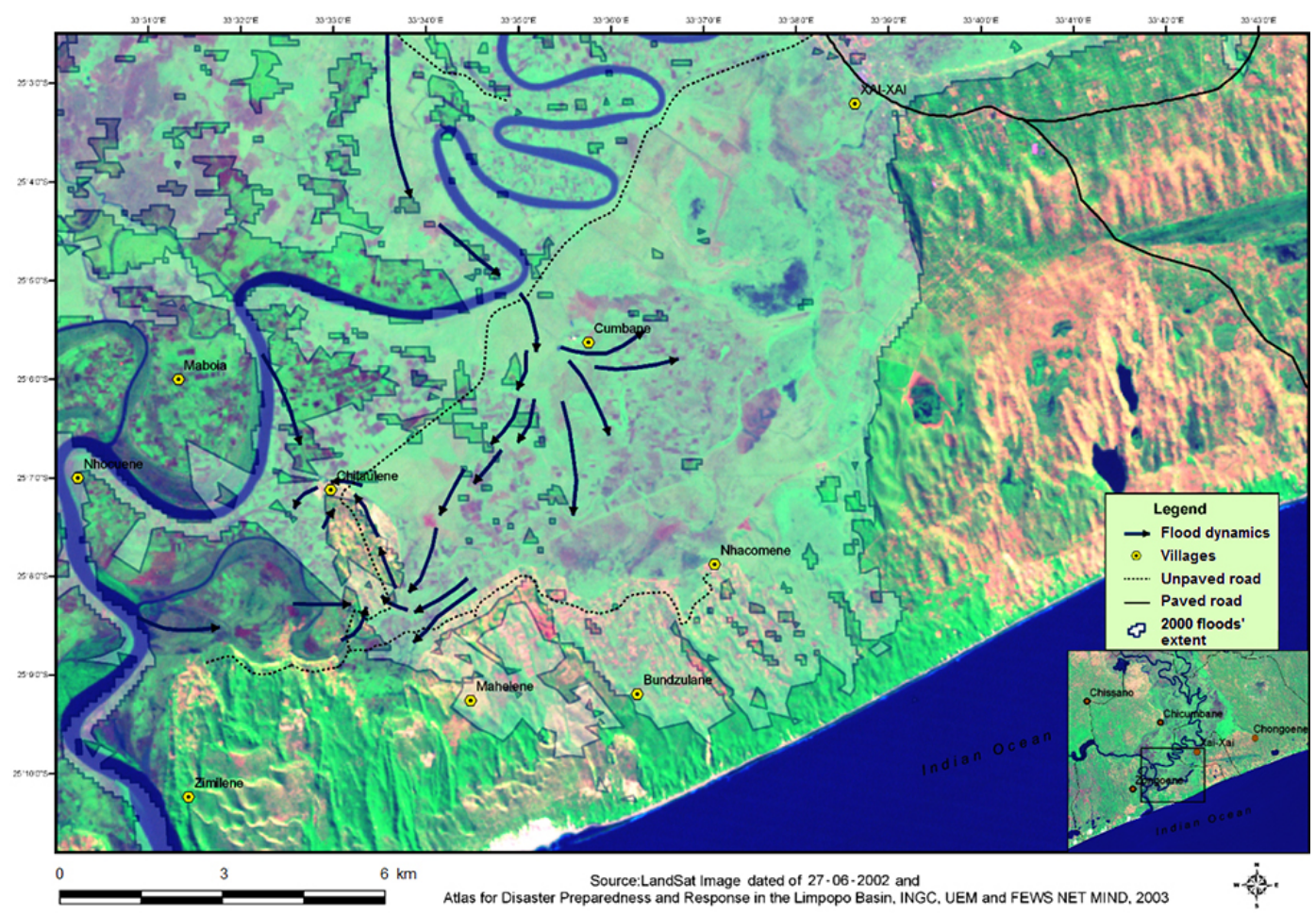

Figure 17. Description of the 2000 flood dynamics in the last stretch of the lower Limpopo (source: Maló and Da Conceição, 2007).

both ancient and active landforms as indicators of levels of landscape stability.

This paper shows that the Limpopo River is a drainage system located in southeastern Africa that exhibits complex geomorphological settings, which result from a series of tectonic activities that have occurred since the late Jurassic period. Apparently abandoned valley floors of the ancient hydrography of the river, which was a much larger fluvial system during the early Cretaceous, are today preferentially occupied by the floodwaters. Particularly vulnerable areas are the broken links between the Limpopo River and the Okavango, upper Zambezi and Cuando rivers, such as Shoshong in Botswana and Shashe in Zimbabwe.

Another very flood-prone territory is most of the area corresponding to the huge palaeo-delta identified in the Mozambican floodplain, which has imposed a peculiar drainage pattern shown by the Shangane River and its tributaries before joining the lower Limpopo. When comparing the maps in Figs. 2, 3, and 4 to the main geomorphological features interpreted in Fig. 12, it appears clear that the floodwaters have been concentrated along the lower area delimited by the mega palaeo-delta, which was built up millions of years ago when the Limpopo River basin was three to four times its current size. The territory defined by the northwest-southeastoriented triangular shape of the palaeo-delta can therefore definitely be considered vulnerable to flooding. In fact, the whole drainage system, which is composed of the rivers
Chigombe, Panzene, Sangutane, Maqueze, Mabengane and Chichacuarre, all ending in the lower Changane River and showing a northwest-southeast orientation before reaching the lower Limpopo River, simply defines the shape of this very ancient deltaic complex. There is therefore a clear influence of the palaeo-delta on the current flood dynamics. Similar flood hazard analysis methods were described by Baker et al. (1988) and Kenny (1990) for data-scarce areas.

In reply to the research question of this paper, the authors conclude that there are definitely clear relationships between flood hazard and the past fluvial changes in the Limpopo River basin. The description of the past river's evolution combined with a geomorphological approach demonstrate, as per what Spaliviero (2003) suggested for the Tagliamento River in northern Italy, that flood hazards tend to be concentrated in the same locations where major fluvial changes have occurred. Accurate and reliable flood hazard information is essential for applying flood mitigation measures in a given territory adequately and for preparing a land-use plan for developing human settlements with reduced vulnerability to this natural hazard.

The Limpopo River basin can be defined as relatively scarce in data, especially when referring to hydraulic and topographic data, which are commonly used to run dynamic flood simulations through spatial models in a geographic information systems environment. The method proposed allows, when considering the natural complexity of the flood 
dynamics of a transboundary river such as the Limpopo, for the identification of unsuitable areas for developing human settlements, which are exposed to high flood hazard connected to the past morphology of the river. The same method could be applied in other river basins of the developing world that show complex flood dynamics.

Acknowledgements. The authors wish sincerely to thank Fenton Cotterill from the University of Stellenbosch, South Africa, and Andy Moore from Rhodes University, South Africa, for the substantial contribution and encouragement towards writing this paper.

Edited by: R. Lasaponara

Reviewed by: R. Drobot and one anonymous referee

\section{References}

Baker, V.: Geomorphological understanding of flooding, Geomorphology, 10, 139-156, 1994.

Baker, V. and Twidale, C.: The reenchantment of geomorphology, Geomorphology, 4, 73-100, 1991.

Baker, V., Kochel, R., and Patton, P.: Flood geomorphology, Wiley Interscience, New York, USA, 503 pp., 1998.

Blum, M. and Törnqvist, T.: Fluvial responses to climate and sealevel change: a review and look forward, Sedimentology, 47, 248, 2000.

Burke, K.: The African plate, S. Afr. J. Geol., 99, 341-409, 1996.

Burke, K. and Gunnell, Y.: The African erosion surface: a continental-scale synthesis of geomorphology, tectonics, and environmental change over the past 180 million years, Geol. Soc. Am. Mem., 201, 1-66, 2008.

Cotterill, F. P. D.: Geomorphological influences on vicariant evolution in some African mammals in the Zambezi Basin: some lessons for conservation, in: Proceedings of an International Symposium on Duiker and Dwarf Antelope in Africa, Filander Verlag, Füurth, Germany, 17-19 February 2003, 11-58, 2003.

De Wit, M. C. J.: Post-Gondwana drainage and the development of diamond placers in western South Africa, Econ. Geol., 94, 721740, 1999.

Dixey, F.: Alex L. du Toit Memorial Lectures No. 4: Some Aspects of the Geomorphology of Central and Southern Africa, the Geological Society of South Africa, the South African Association for the Advancement of Science and the South African Geographical Society, Hortors Limited, Johannesburg, South Africa, 56 pp., 1955.

Du Toit, A.: Crustal movement as a factor in the geographic evolution of South Africa, S. Afr. Geogr. J., 41, 3-20, 1933.

Fohrer, N.: Recent developments in river basin research and management, Phys. Chem. Earth, Pts. A/B/C, 28, 1279-1388, 2003.

Gilvear, D.: Fluvial geomorphology and river engineering: future roles utilizing a fluvial hydrosystems framework, Geomorphology, 31, 229-245, 1999.

Goudie, A. S.: The drainage of Africa since the Cretaceous, Geomorphology, 67, 437-456, 2005.

Hickin E.: River channel changes: retrospect and prospect, in: Modern and Ancient Fluvial Systems, Special Publication 6 of the Interntional Association of Sedimentologists, edited by: Collison,
J. and Lewin, J., Blackwell Scientific Publications, Oxford, UK, 61-83, 1983.

INGC, UEM, FEWS NET MIND: Atlas for Disaster Preparedness and Response in the Limpopo Basin, Maputo, Mozambique, 156 pp., 2003.

Kauffman, G. J.: What if ... the United States of America were based on watersheds?, Water Policy, 4, 57-68, 2002.

Kenny, R.: Hydrogeomorphic flood hazard evaluation for semi-arid environments, Q. J. Eng. Geol., 23, 333-336, 1990.

King, L. C.: The South African Scenery, edited by: Oliver and Boyd, Edinburgh, UK, 308 pp., 1963.

Kundzewicz, Z. W., Budhakooncharoen, S., Bronstert, A., Hoff, H., Lettenmaier, D., Menzel, L., and Schulze, R.: Coping with variability and change: Floods and droughts, Nat. Resour. Forum, 26, 263-274, 2002.

Lister, L. A.: The erosion surfaces of Zimbabwe, Zimbabwe Geological Survey, Harare, Zimbabwe, 163 pp., 1987.

Maló, S. and Da Conceição, P. J.: Mapping and Spatial Analysis Results, UN-Habitat/UNEP Limpopo Project, unpublished, Nairobi, Kenya, 28 pp., 2007.

Maufe, H. B.: Some factors in the geographical evolution of southern Rhodesia and neighbouring countries, S. Afr. Geogr. J., 43, $1-21,1935$.

Moore, A. E.: A reappraisal of epeirogenic flexure axes in southern Africa, S. Afr. J. Geol., 102, 363-376, 1999.

Moore, A. E. and Blenkinsop, T.: The role of mantle plumes in the development of continental-scale drainage patterns: the southern African example revisited, S. Afr. J. Geol., 105, 353-360, 2002.

Moore, A. E. and Larkin, P. A.: Drainage evolution in south-central Africa since the breakup of Gondwana, S. Afr. J. Geol., 104, 4768, 2001.

Moore, A. E., Cotterill, F. P. D., Main, M. P. L., and Williams, H. B.: The Zambezi River, in: Large Rivers: Geomorphology and Management, edited by: Gupta, A., John Wiley \& Sons Ltd., London, UK, 311-332, 2007.

Moore, A. E., Blenkinsop, T., and Cotterill, F. P. D.: Controls on post-Gondwana alkaline volcanism in Southern Africa, Earth Planet. Sc. Lett., 268, 151-164, 2008.

Moore, A. E., Cotterill, F. P. D., Broderick, T., and Plowes, D.: Landscape evolution in Zimbabwe from the Permian to present, with implications for kimberlite prospecting, S. Afr. J. Geol., 112, 65-88, 2009a.

Moore, A. E., Blenkinsop, T., and Cotterill, F. P. D.: Southern African topography and erosion history: plumes or plate tectonics?, Terra Nova, 21, 310-315, 2009b.

Mpho, T.: Developing participatory land use tools and plans for sustainable land management in Shoshong Village and Taung Ward, Ramotswa, of Botswana's Limpopo River basin, in order to reduce the impact of floods on land, ecosystems and human settlements, UN-Habitat/UNEP Limpopo Project, unpublished, Nairobi, Kenya, 53 pp., 2007.

Murwira, A., Madamombe, E.K., Shidziva, E., and Kaseke, E.: Sustainable land use planning for disaster preparedness and vulnerability reduction in the Limpopo River basin: Zimbabwe component, UN-Habitat/UNEP Limpopo Project, unpublished, Nairobi, Kenya, 57 pp., 2006.

Newson, M.: Geomorphological concepts and tools for sustainable river ecosystem management, Aquat. Conserv., 12, 365379, 2002. 
OCHA ROSA, Southern Africa: Floods Situation Report No. 5 (as of 8 February 2013), available at: http://www.unocha.org/rosa/ reports-media/ocha-reports?page $=3$, last access: 14 June 2014, 2013.

Pahuja, S. and Goswami, D.: A fluvial geomorphology perspective on the knowledge base of the Brahmaputra - Background Paper n. 3 commissioned as an input to the study Development and Growth in Northeast India: the Natural Resources, Water, and Environment Nexus, 2006.

Parker, D. C., Hessl, A., and Davis, S. C.: Complexity, land-use modeling, and the human dimension: Fundamental challenges for mapping unknown outcome spaces, Geoforum, 39, 789-804, 2008.

Partridge, T. C.: Of diamonds, dinosaurs and distrophism 150 million years of landscape evolution in southern Africa, 25th Alex du Toit Memorial Lecture, S. Afr. J. Geol., 101, 167-184, 1998.

Partridge, T. C. and Maud, R. R.: Geomorphic evolution of southern Africa since the Mesozoic, S. Afr. J. Geol., 90, 179-208, 1987.

Pilkey, O. H. and Pilkey-Jarvis, L.: Useless Arithmetic: Why Environmental Scientists Can't Predict the Future, Columbia University Press, New York, USA, 230 pp., 2007.

Potter, P. E.: Significance and origin of big rivers, J. Geol., 86, 1333, 1978.
Salman, G. and Abdula, I.: Development of the Mozambique and Ruvuma sedimentary basins, offshore Mozambique, Sediment. Geol., 96, 7-41, 1995.

Spaliviero, M.: Historic fluvial development of the Alpine-foreland Tagliamento River, Italy, and consequences for floodplain management, Geomorphology, 52, 317-333, 2003.

Spaliviero, M., De Dapper, M., Mannaerts, C., and Yachan, A.: Participatory Approach for Integrated Basin Planning with Focus on Disaster Risk Reduction: the Case of the Limpopo River, Water, 3, 737-763, 2011.

Steinberg, A.: Flood Control of the Willamette River, Willamette River Health, Clark Honors College, University of Oregon, USA, 2004.

Wallick, J. R., Grant, G. E., Lancaster, S. T., Bolte, J. P., and Denlinger, R. P.: Patterns and Controls on Historical Channel Change in the Willamette River, Oregon, USA, in: Large Rivers: Geomorphology and Management, edited by: Gupta, A., John Wiley \& Sons Ltd., 491-516, 2007.

White, R. S.: Mantle plume origin for the Karoo and Ventersdorp flood basalts, South Africa, S. Afr. J. Geol., 100, 271-282, 1997.

Wilkinson, M. J.: Megafans and continental sedimentation: New concepts in African exploration, in: Africa Upstream 2004 Conference, 6-8 October 2004, Cape Town, South Africa, 2004. 